\title{
Production Determinants Impact among Marketing Management on Improving Marketing Mix for Livestock Wealth in Jordan: Viewpoint of Livestock Breeders
}

\author{
Mahmud Aqel Abu Dalbouh ${ }^{1}$ \\ ${ }^{1}$ Marketing Department, Irbid National University, Jordan \\ Correspondence: Mahmud Aqel Abu Dalbouh, Marketing Department, Irbid National University, Jordan. E-mail: \\ M_agel_dlb@yahoo.com
}

Received: February 11, 2020

Accepted: April 14, 2020

Online Published: May 17, 2020

doi:10.5539/ijbm.v15n6p137

URL: https://doi.org/10.5539/ijbm.v15n6p137

\begin{abstract}
The research aimed to know the "impact of marketing production determinants on improving marketing mix at livestock industry "according to the perspective on Jordanian sector marketing for "livestock breeders(LB), competitors, laws policies(LP) and due it to its importance, it focuses on addressing the limitations faced by the production of livestock sector in Jordan, the research showed public and private limitations facing the Jordanian livestock sector production and performance according to the perspective of change in market, customers and marketing activities (3).

The research dimensions consist of many variables: planning, organizing, co-operation, cost, experience, competition, nutrition sources, diseases, government support, new technology, production, and performance of the livestock wealth sector(LWS), the research population included the breeders in livestock in Jordan and supporters amounting to (25000), the research sample consists of (500) farmer who was randomly selected, in collecting data the researcher depends on elementary and secondary resources and supported them with related studies. The relevance needs for improving the marketing mix and the development of practical recommendations taking into account the transformations of the global market and the rapid development of innovative technologies (6).

The author had been defining the determinants of livestock wealth production effects interactive marketing management and proposed the main stages improving its marketing mix by analyzing (6) - (8) variables, which everyone will allow as an approach for improving the new marketing mix.

The research concluded that the production and performance face limitations to marketing activities in the Jordanian livestock sector and it has a gap of the management functions, changing requirements, (the gap of production, performance) with limitations as cost, experience, competition, nutrition sources, diseases, government support, all variables affecting without organizing and cooperation, The research recommended that must be reorganizing the Jordanian livestock sector, come over the determinants, and exploit a new marketing management strategy for livestock mix.
\end{abstract}

Keywords: livestock wealth sector (LWS), determinants, production, performance, experience, competition, nutrition sources, diseases, government support (GS), livestock breeders (LB), new technology, marketing management

\section{Introduction}

Under the global economy transformation(GET) The marketing is the influence of the process marketing mix and led the rapid improving by innovative technology, the key issues of managing organizations performance the production of livestock wealth and improving the marketing mix and overcome the determinants (3)-(4)-(6). The contribution overcomes the determinants consider as a basis for developing a new marketing mix, the impact of market shifts and changes lead to volatility which must be considered into adaptation by managerial decisions to intensive technology (32)-(44).

The importance of marketing (IM) is related to many reasons, it has entered all the public aspects of, economic, political, legal, social, cultural, competition, technology, in addition to many private aspects as, dynamic 
evolution, the variance of customers characteristics (CC), interest groups, organizations changes, (11)-(17) imposes on the marketing production (MP), performance in Jordanian livestock activities (PJLA), multiple challenges(limitations) industry making the marketing process more complex under technological acceleration, information revolution(IR), and international, regional and local transformations (7).

depend above, market imposes tough conditions on marketers, performance, production, and the bargaining power now tend to positive the market factors (16), which makes the factors of production and marketing work hard in order to improve the marketing performance to achieve the needs and desires of individuals in order to reach to customers satisfaction (19), the livestock farmers are being great importance: faces limitations and try to focus on evaluating, solving many problems, applying new strategies, new methods, employees rehabilitation (ER), increasing cooperation, interaction between administration and employees for achieving livestock breeders goals (8).

Depend on(agricultural statics -July-2015) for livestock sector, the number of sheep's is 2,7 million, goats 875 000 , cows 70000 , but the requirements of livestock sector is 805 million, the cost of transportation is $34 \%$, the number of farms 3248, finally the participation of gross national product is 1190/11642 million\$ but livestock wealth participation is 465 million.

\subsection{Actual Scientific Researches and Issues Analysis}

The development needs an effective marketing mix is one of the most basic strategic directions. It depends on overcoming all limitations at the livestock industry to select a new marketing mix for achieving a competitive position in the market (36)-(39). to study the basic concepts of marketing, ought to consider the evolution of entrances to the formation of the marketing mix, there are 12-element for marketing mix which may exploit to enhance productions and understand the combination of marketing elements to achieve goals and meet target market (5)-(6).

The determinants of livestock wealth industry was determined by analyzing it to choose basic marketing tools for overcoming to formulate new marketing mix strategy (1), for r-organize marketing mix to lead it ought modification the stricture and expansion of the standard set of its components to classifying the needs, wants and include elements in its stricture that directly determine the final result of marketing activities, over that study internal resources for creating and improving in livestock wealth industry(LWI) (1)-(6).

\subsection{General matters Defining}

Depend on The theoretical research information analyzing there is a problem meet the livestock breeders as the determinants that hinder the livestock wealth, marketing mix marketing management that would take into account the influence of all factors using innovate method to overcome (6) it should be there are needs to systemize entrances to determine the marketing mix and restructure new productions, the new technology is help to avoid many determinants and turn lead for improving existence new methods, new strategies, new marketing mix the livestock wealth in Jordan face many determinants in light absence of the Planning, government attitudes, control, globalization, new markets, digital revolution, Customer care, Rapid changes, High degree of competition, the efficiency of government, care health, protect of diseases, cost, technology (1)-(3)-(5).

\subsection{Purpose, Importance of the Research}

Depend on research importance, the purpose is improving marketing mix in livestock wealth industry by determines the following determinants (31)-(46).

Knowledge of livestock sector orientation depends on market terms as, breeders, customers, competitors, cooperation (1)(28), the Role of marketing on the processes of production, performance, supply and demand, the Extent the livestock performance to achieves satisfaction, the loyalty Meet the limitations in livestock wealth. These studies depend on marketing orientation to support livestock wealth in Jordan the Availability resources of necessity and requirements in the livestock sector to meet the market requirements and the infrastructure tools (1).

\subsection{Material and Methods of the Research}

The theoretical and methodological fundamentals research is focused on new marketing theory, in process of the research, the general scientific methods to cognition of analyzing and synthesis to improve practical recommendations about improving new marketing mix(2), the information base of research was the data of breeders, agriculture reports, articles, annual reports of agriculture ministry, scientific paper, marketers, questioner, interviews, and notes.

The researcher adopted the descriptive and analytical approach to study the Jordanian livestock sector and apply 
the research by breeders viewpoint, because the breeders closely and face limitation for developing their wealth in the livestock sector and deal with breeders random regular sample by $10 \%$, research Population is 57340 employee, Population is $(5000)$ breeders (1), $10 \%$ of $5000=(500)$ breeders of the research population, a questionnaire was sent to a number of professors and professionals for arbitration, the researcher has conducted by distributing (20) questionnaire, retrieved (16) in the first time and repeat again in the same number, but retrieved (18), where the percentage of questionnaire stability was $(85 \%)$, the researcher uses random sample.

\subsection{Key findings of the Research}

Many economies in the world try on developing and improving to meet the market requirements, globalization, changes, new technology, and promotion tools. so that we ought to care with and keep on competitive advantages for analyzing constantly the customers, market, needs, wants, production, competitors, and modification by new strategy to overcome all determinants for improving new marketing mix, and try many times to create new tools keep constantly improving (1)-(6).

In 21 century, the basic rules of marketing is changed, on the other hand, the livestock wealth sector ought to change strategy, policies, tools, therefore it should be across the obstacles and control to success and formulation new marketing mix depends on (4-12ps) dimensions as product, price, place, promotion, personnel, sales, packaging, physical evidence, planning, plan of ads, plan of demonstration. The performance, production, marketing activities need to processes continuous development of harmony with the forces of the total and dynamic environment, interacting with the rapid changes of livestock requirements so as to increase the ability of livestock organizations, and breeders to achieve their general and detailed objectives (22).

The business organizations, breeders, focusing and restructuring the livestock marketing mix(production )in addition to urgent need for information and provision of intellectual capital to manage the marketing process, performance, the marketing research, consumer behavior, livestock situation, breeders attitudes, analysis sales, marketing opportunities have become necessity preceding the planning of livestock performance in addition for developing (19)-(25), the model explains that improving marketing mix affected at (.,88) but the marketing management affected at $(., 86)$ on the seam attitude the correlation coefficient explains that improving marketing mix strategy affected by (0.79), marketing management affected by (0.589), was appropriated by (.97), ANOVAs was significant at (000), finally, all variables affected without organizing and cooperation.

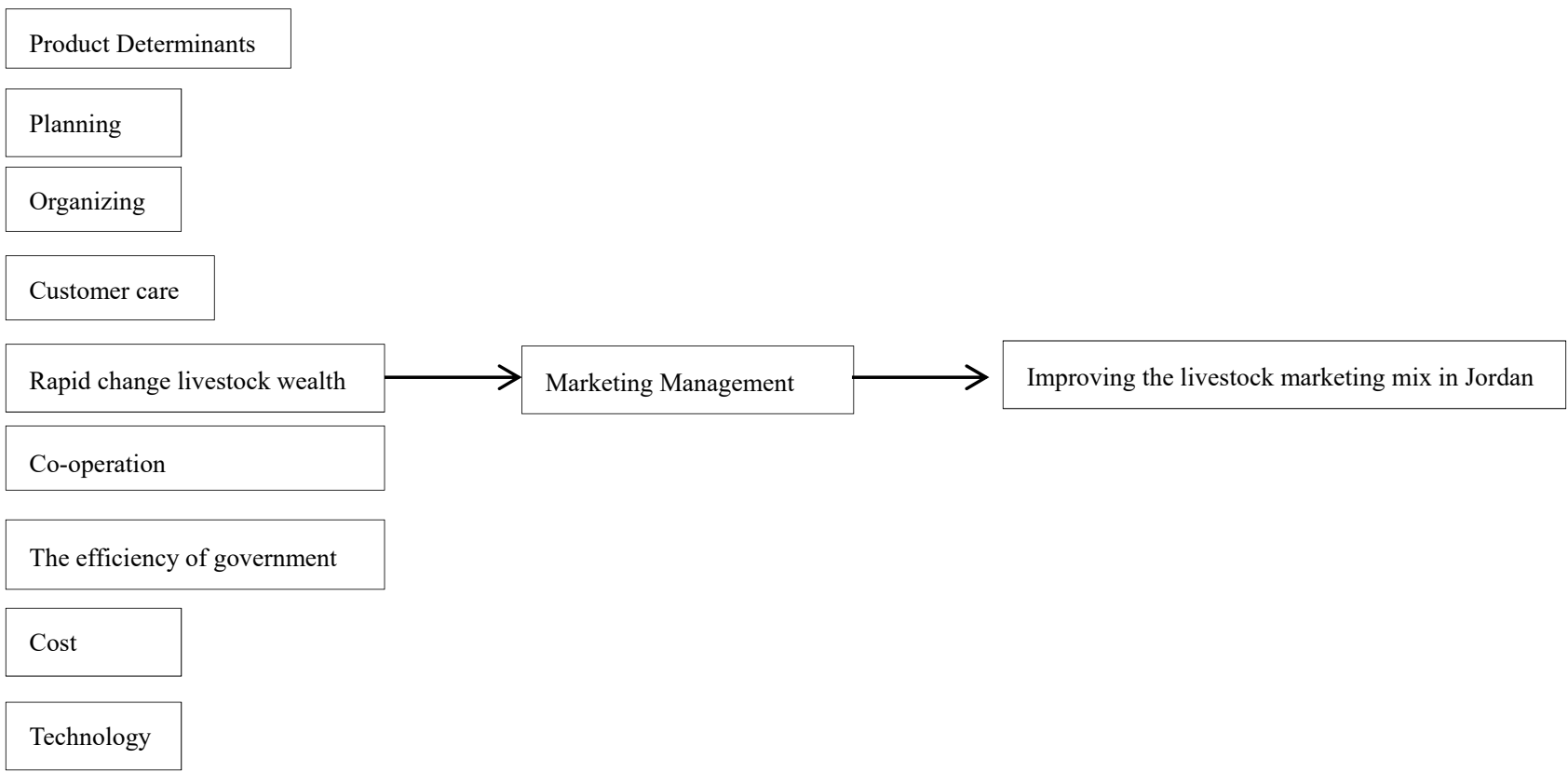

Figure 1. Model of the study

The Source: Researcher (6).

\section{Research Methodology}

For the purpose of carrying out the research, a number of methods were used to collect information and data 
through Secondary data represented by books, references, periodicals, relevant research, and websites related to the determinants of production and improving the marketing mix. Also, it relied on Primary data represented to identify the study that was considered the main tool for measuring variables and study dimensions associated with hypotheses. The research population and sample: This research targeted Jordanian farmers in various governorates, and the number of these farmers was obtained from the Department of Statistics, which numbered (5000) farmers. A simple Random Sample of 500 farmers was chosen to represent the research society.

\subsection{The Statistical Methods}

Stepwise regression was used. Depending on the value of the T-test and the F test and their level of significance (Sig), the relationship between the production parameters and the improvement of the marketing mix were tested. The correlation test was used to determine the direction of the relationship or effect between the dependent variable and the independent variables. This analysis came in line with the AMOS program to verify the goodness of the model and the statistical program (SPSS) using simple and multiple linear regressions. Correlation coefficients were used to verify the validity of the tool, and the Cronbach Alpha test to verify the reliability of the tool.

A special questionnaire was designed for a research: it was prepared based on the studies and literature that dealt with this topic, as the questionnaire contained (55) questions that asked the participants to choose the response that corresponds to their opinions, as this questionnaire was designed to determinants production impact among marketing management for improving the marketing mix for livestock wealth in Jordan. The response rate has reached $(92 \%)$, which is the rate that represents the questionnaires on which the analysis was conducted at (500) questionnaires. Likert scale was used to measure the study variables, the marketing management affected on determinants and enhanced it to exploit the adaptation for overcoming and improve the new marketing mix.

\section{Conclusion}

Depend on research results and analyzing it, The research examined the determinants which face improving marketing mix in Jordan livestock wealth, by using marketing management strategies, in-depth the determinants easy to remove its effects by little efforts after that adaptation with new marketing management, the results had been all variables affected except organizing, cooperation, the livestock sector ought to use marketing management strategies to forum and improving marketing mix the research recommendled to support livestock sector, decrease the cost, inter new regional markets, and improve the goals of livestock organizations.

The sector ought to use marketing mix strategy interactively to affect at livestock industry, the new marketing management strategy focus on re-organizing, re-cooperation, re-build new strategy in marketing management which helping in livestock wealth sector, improve and transfer technology, improve breeders skills organizing, training, promotion programs, focus on government efforts and attitudes.

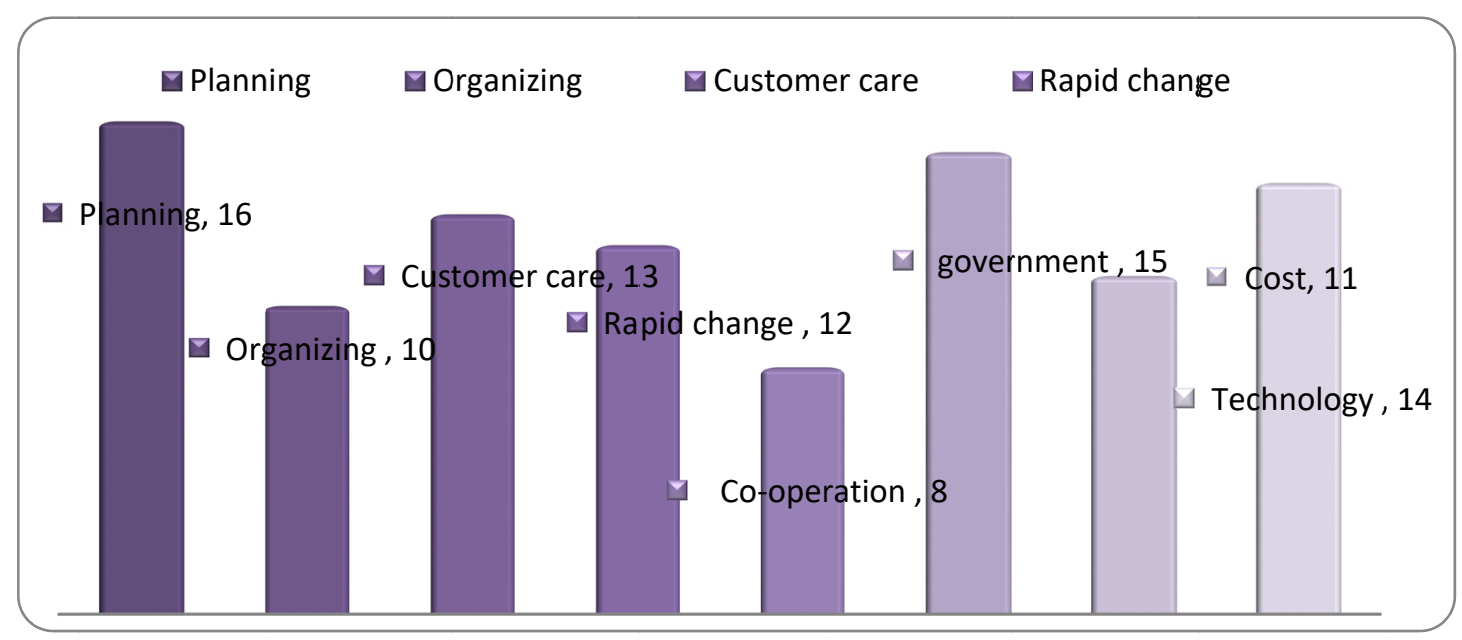

Figure 1. The production determinants

The Source: Researcher (6). 


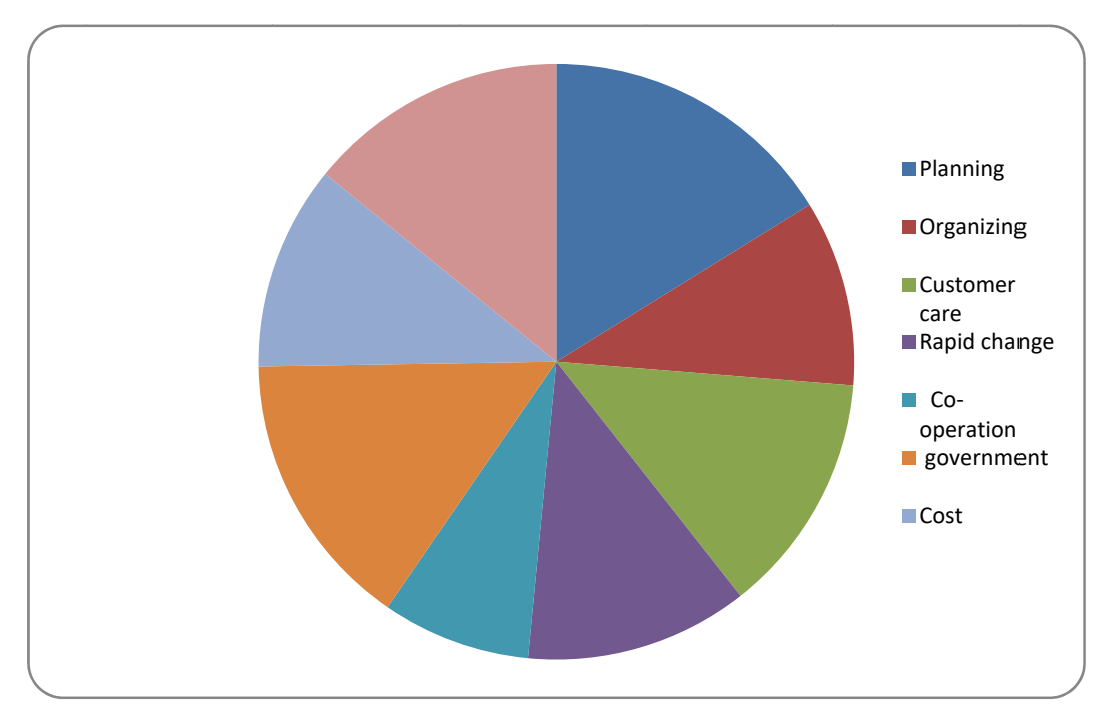

Determinants Production

Marketing management

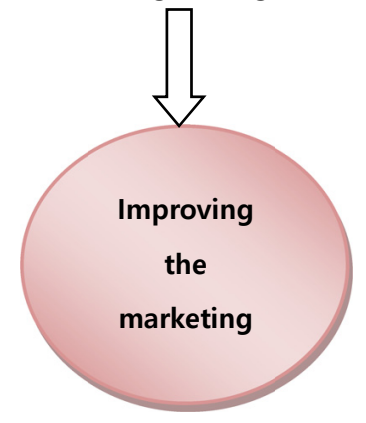

\subsection{The Reliability of the Study Tool}

The (Cronbach's Alpha) test was used to measure the reliability of the instrument as shown in Table 1. The alpha value of the variables that measure the dependent variable was (0.88). As for the value of (Alpha) for the independent variables, it reached (0.82), which is a statistically acceptable percentage. (Sekaran, 2000).

Table 1. Estimation of reliability coefficients

\begin{tabular}{ll}
\hline Variables & Alpha \\
\hline Planning & 0.87 \\
Organization & 0.77 \\
Customer care & 0.80 \\
Rapid changes & 0.74 \\
cooperation & 0.71 \\
government Efficiency & 0.83 \\
cost & 0.81 \\
Technology & 0.78 \\
improving the marketing mix & 0.88 \\
Marketing management & 0.86 \\
\hline
\end{tabular}

A Variance Inflation Factor VIF and a Tolerance test were performed for each of the independent variables in order to know the extent of the existence of a self-correlation between the independent variables (Multi-collinearity), where the value of (VIF) for all the independent variables was less than (10) and that the allowable variance value for all independent variables less than $(0.05)$, this means that there is no real problem related to the existence of a high correlation between the independent variables (Shatoush, 2001) The validity of 
the study tool.

The Pearson correlation coefficient was used to verify the validity of the study tool, by calculating the relationship between each paragraph and the subtotal of the independent variable to which it belongs and the total sum of the tool.

Table 2. Pearson correlation coefficients for the study tool's paragraphs and variables

\begin{tabular}{ll}
\hline \multicolumn{1}{c}{ No. } & $\begin{array}{l}\text { Coefficient of correlation } \\
\text { with the variable }\end{array}$ \\
\hline $\begin{array}{l}\text { Planning -Coefficient of correlation of the } \\
\text { variable with the tool }\end{array}$ & $0.722^{* *}$ \\
Organizing -Coefficient of correlation & $0.745^{* *}$ \\
Customer care -Coefficient of correlation & $.804^{* *} 0$ \\
Rapid changes -Coefficient of correlation & $0.825^{* *}$ \\
Cooperation- Coefficient of correlation & $0.842^{* *}$ \\
government Efficiency -Coefficient of the tool & $0.847^{* *}$ \\
correlation & $.778^{* *} 0$ \\
cost -Coefficient of correlation & $0.714^{* *}$ \\
Technology -Coefficient of correlation & $0.790^{* *}$ \\
improving the marketing mix -Coefficient of \\
correlation
\end{tabular}

It is clear from the previous table that all correlation coefficients were a function at the function level $(\alpha=0.01)$, which confirms the validity of the construction of the study instrument and its suitability for application to the study sample. The Goodness of fit to the study model: Using the AMOS program, the researcher examined goodness of fit with the study model as follows.

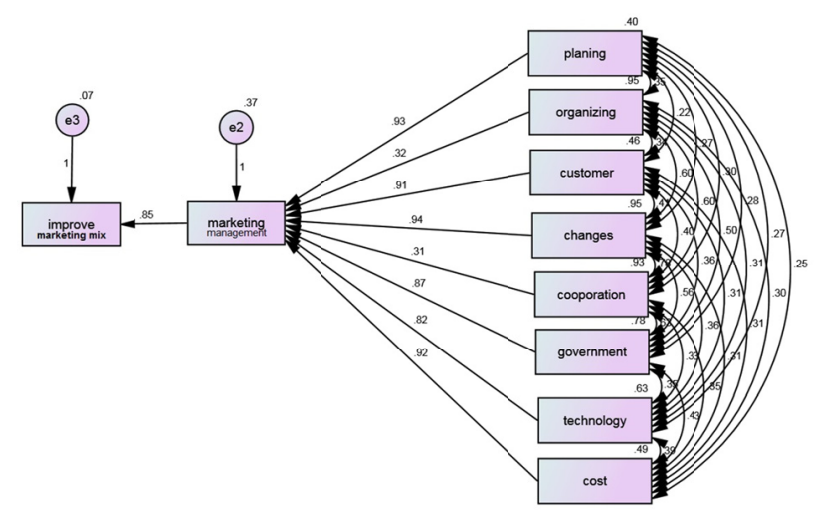

Figure 2. Study model

Table 3. Goodness of fit

\begin{tabular}{lll}
\hline indicator & value & \\
\hline GFI & 0.91 & Identical \\
X2 & 5.689 & Identical \\
RMSEA & 0.42 & Identical \\
TLI & 0.92 & Identical \\
NFI & 0.93 & Identical \\
AGFI & 0.94 & Identical \\
PCFI & 0.94 & Identical \\
\hline
\end{tabular}




\subsection{Research Hypotheses Test}

To examine the hypothesis of the main study, Stepwise Regress was used. Depending on the value of the T-test and the $\mathrm{F}$ test and their level of significance (Sig), the relationship between production parameters and the improvement of the marketing mix were tested. The correlation was also used to determine the direction of the relationship or effect between the dependent variable and the independent variables.

Main hypothesis: There is no statistically significant effect at the level of significance $(\alpha \geq 0.05)$ of the determinants of production by marketing management in improving the marketing mix for livestock wealth in Jordan.

To test this hypothesis, the researcher used a Stepwise regression analysis as follows: Table No. (5) Stepwise regression analysis for the determinants of production in improving the marketing mix for livestock wealth in Jordan.

Table 4. Model summary

\begin{tabular}{lllll}
\hline & & & & \multicolumn{2}{l}{ Std. An error of the } \\
Model & $\mathrm{R}$ & R Square & Adjusted R Square & Estimate \\
\hline 1 & $.988 \mathrm{a}$ & .976 & .976 & .10170 \\
\hline
\end{tabular}

a. Predictors: (Constant), technology, organizing, government efficiency, planning, customer, rapid changes, cost, cooperation.

It is clear from the previous table that the production determinants explain the amount (97.6\%) of the marketing mix of livestock in Jordan.

Table 5 ANOVA analysis for the determinants of production in improving the marketing mix for livestock wealth in Jordan.

Table 5. ANOVAs

\begin{tabular}{lllllll}
\hline Model & & Sum of Squares & $\mathrm{df}$ & Mean Square & $\mathrm{F}$ & Sig. \\
\hline 1 & Regression & 210.211 & 8 & 26.276 & 2540.376 & $.000 \mathrm{~b}$ \\
& Residual & 5.079 & 491 & .010 & & \\
& Total & 215.290 & 499 & & & \\
\hline
\end{tabular}

a. Dependent Variable: improve marketing mix.

b. Predictors: (Constant), technology, organizing, government efficiency, planning, customer, rapid changes, cost, cooperation.

It is clear from the previous table that there is a statistically significant effect of the determinants of production in improving the marketing mix of livestock in Jordan, as the calculated value of (sig) reached $(0.000)$ which is less than the level of the $(\alpha \geq 0.05)$, thus rejecting the nihilistic hypothesis and accepting the hypothesis The alternative states that there is a statistically significant effect of the determinants of production on improving the marketing mix of livestock in Jordan.

Table 6. Coefficients Values of determinants production

\begin{tabular}{|c|c|c|c|c|c|c|}
\hline \multirow[b]{2}{*}{ Model } & & \multicolumn{2}{|c|}{ Unstandardized Coefficients } & \multirow{2}{*}{$\begin{array}{l}\text { Standardized } \\
\text { Coefficients } \\
\text { Beta }\end{array}$} & \multirow[b]{2}{*}{$\mathrm{t}$} & \multirow[b]{2}{*}{ Sig. } \\
\hline & & $\mathrm{B}$ & Std. Error & & & \\
\hline \multirow[t]{9}{*}{1} & (Constant) & 0.026 & 0.033 & & 0.801 & .424 \\
\hline & planning & 0.792 & 0.010 & 0.759 & 79.076 & 0.000 \\
\hline & organizing & -0.005 & 0.009 & -0.008 & -.580 & 0.562 \\
\hline & customer & -0.041 & 0.010 & -0.042 & -3.964 & 0.000 \\
\hline & rapid changes & 0.254 & 0.007 & 0.377 & 37.383 & 0.000 \\
\hline & cooperation & 0.002 & 0.010 & 0.002 & .154 & 0.878 \\
\hline & government efficiency & -0.045 & 0.009 & -0.044 & 12.658 & 0.000 \\
\hline & $\operatorname{cost}$ & 0.052 & 0.012 & 0.048 & 17.629 & 0.000 \\
\hline & technology & 0.044 & 0.009 & 0.044 & 22.430 & 0.000 \\
\hline
\end{tabular}

a. Dependent Variable: improve marketing mix. 
Coefficients values for independent variables show that there is a statistically significant effect for each of(Planning, and Customer care and Rapid changes and government Efficiency and cost and Technology As the calculated value ( $\mathrm{sig}$ ) for all of them are less than the value of the significance level $(\alpha \geq 0.05)$, Whereas, there was no statistically significant effect at the significance level $(\alpha \geq 0.05)$ of each of the Organization and cooperation, the calculated value of ( $\mathrm{sig}$ ) has reached (0.562) (0.878), respectively, which is greater than the value of the function level in this study.

The researcher also used simple regression analysis to examine the sub-study hypotheses as follows:

The first sub-hypothesis: There is no statistically significant effect at the significance level $(\alpha \geq 0.05)$ to planning on improving the marketing mix of livestock in Jordan.

Table 7. Simple linear regression analysis of the planning variable

\begin{tabular}{|c|c|c|c|c|}
\hline \multirow{2}{*}{\multicolumn{5}{|c|}{ Model Summary }} \\
\hline & & & & \\
\hline & & & & $\begin{array}{l}\text { Std. An error of the } \\
\text { Estimate }\end{array}$ \\
\hline $\begin{array}{l}\text { Model } \\
1\end{array}$ & $\begin{array}{l}\mathrm{R} \\
934 \mathrm{a}\end{array}$ & $\begin{array}{l}\text { R Square } \\
891\end{array}$ & $\begin{array}{l}\text { Adjusted R Square } \\
.891\end{array}$ & $\begin{array}{l}\text { Estimate } \\
.21697\end{array}$ \\
\hline
\end{tabular}

It is clear from the previous table that the planning variable explains the amount $(89.1 \%)$ of improving the marketing mix of livestock in Jordan.

Table 8. Analysis of variance of the planning variable

\begin{tabular}{lllllll}
\hline \multicolumn{2}{l}{ ANOVAs } & & & & & \\
\hline Model & & Sum of Squares & df & Mean Square & F & Sig. \\
\hline 1 & Regression & 191.846 & 1 & 191.846 & 4075.149 & $.000 \mathrm{~b}$ \\
& Residual & 23.444 & 498 & .047 & & \\
& Total & 215.290 & 499 & & & \\
\hline
\end{tabular}

a. Dependent Variable: improve marketing mix

b. Predictors: (Constant), planning.

It is clear from the previous table that there is a statistically significant effect of the planning variable in improving the marketing mix of livestock in Jordan, as the calculated value (sig) reached (0.000) which is less than the level of significance $(\alpha \geq 0.05)$, thus rejecting the nihilistic hypothesis and accepting the alternative which it states that there is an effect of planning in improving the marketing mix of livestock in Jordan.

Sub-second hypothesis: There is no statistically significant effect at the significance level $(\alpha \geq 0.05)$ to Organization on improving the marketing mix of livestock in Jordan.

Table 9. Simple linear regression analysis of the organization variable

\begin{tabular}{lllll}
\hline Model Summary & & & \\
\hline & & & & Std. An error of the \\
Model & R & R Square & Adjusted R Square & Estimate \\
\hline 1 & $.321 \mathrm{a}$ & .211 & .191 & .71604 \\
\hline
\end{tabular}

a. Predictors: (Constant), organizing.

It is clear from the previous table that the Organization variable explains the amount (19.1\%) of improving the marketing mix of livestock in Jordan. 
Table 10. Analysis of variance of the organization variable

\begin{tabular}{|c|c|c|c|c|c|c|}
\hline \multicolumn{7}{|c|}{ ANOVAs } \\
\hline & & Sum of Squares & $\mathrm{df}$ & Mean Square & $\mathrm{F}$ & Sig. \\
\hline \multirow[t]{3}{*}{1} & Regression & 0.091 & 1 & 0.091 & 0.210 & $.562 \mathrm{~b}$ \\
\hline & Residual & 215.199 & 498 & .432 & & \\
\hline & Total & 215.290 & 499 & & & \\
\hline
\end{tabular}

a. Dependent Variable: improve marketing mix.

b. Predictors: (Constant), organizing.

It is clear from the previous table that there is no statistically significant effect of the organizing variable in improving the marketing mix of livestock in Jordan, as the calculated value (sig) reached (0.562) which is bigger than the level of significance ( $\alpha \geq 0.05)$.

Sub-third hypothesis: There is no statistically significant effect at the significance level $(\alpha \geq 0.05)$ to Customer care on improving the marketing mix of livestock in Jordan.

Table 11. Simple linear regression analysis of the customer care variable

\begin{tabular}{lllll}
\hline \multicolumn{3}{l}{ Model Summary } & & \\
Model & $\mathrm{R}$ & R Square & Adjusted R Square & Estimate \\
\hline 1 & $.928 \mathrm{a}$ & 0.911 & 0.911 & .55287 \\
\hline
\end{tabular}

a. Predictors: (Constant), Customer care.

It is clear from the previous table that the Customer care variable explains the amount $(91.1 \%)$ of improving the marketing mix of livestock in Jordan.

Table 12. Analysis of variance of the customer care variable

\begin{tabular}{lllllll}
\hline $\begin{array}{l}\text { ANOVAs } \\
\text { Model }\end{array}$ & & Sum of Squares & df & Mean Square & F & Sig. \\
\hline 1 & Regression & 63.071 & 1 & 63.071 & 206.342 & $.000 \mathrm{~b}$ \\
& Residual & 152.219 & 498 & .306 & & \\
& Total & 215.290 & 499 & & & \\
\hline
\end{tabular}

a. Dependent Variable: improve marketing mix

b. Predictors: (Constant), customer care.

It is clear from the previous table that there is a statistically significant effect of the customer care variable in improving the marketing mix of livestock in Jordan, as the calculated value (sig) reached $(0.000)$ which is less than the level of significance $(\alpha \geq 0.05)$, thus rejecting the nihilistic hypothesis and accepting the alternative which it states that there is an effect of customer care in improving the marketing mix of livestock in Jordan.

Sub-fourth hypothesis: There is no statistically significant effect at the significance level $(\alpha \geq 0.05)$ Rapid changes in improving the marketing mix of livestock in Jordan.

Table 13. Simple linear regression analysis of the to rapid changes variable

\begin{tabular}{lllll}
\hline Model Summary & & & \\
& & & & Std. An error of the \\
Model & $\mathrm{R}$ & R Square & Adjusted R Square & Estimate \\
\hline 1 & $.958 \mathrm{a}$ & .941 & .941 & .25540 \\
\hline
\end{tabular}

a. Predictors: (Constant), rapid changes. 
It is clear from the previous table that the rapid changes variable explains the amount $(94.1 \%)$ of improving the marketing mix of livestock in Jordan.

Table 14. Analysis of variance of the rapid changes variable

\begin{tabular}{|c|c|c|c|c|c|c|}
\hline \multicolumn{7}{|c|}{ ANOVAs } \\
\hline & & Sum of Squares & $\mathrm{df}$ & Mean Square & $\mathrm{F}$ & Sig. \\
\hline \multirow[t]{3}{*}{1} & Regression & 61.673 & 1 & 61.673 & 199.932 & $.000 \mathrm{~b}$ \\
\hline & Residual & 153.617 & 498 & .308 & & \\
\hline & Total & 215.290 & 499 & & & \\
\hline
\end{tabular}

a. Dependent Variable: improve marketing mix.

b. Predictors: (Constant), rapid changes.

It is clear from the previous table that there is a statistically significant effect of the rapid changes variable in improving the marketing mix of livestock in Jordan, as the calculated value (sig) reached (0.000) which is less than the level of significance $(\alpha \geq 0.05)$, thus rejecting the nihilistic hypothesis and accepting the alternative which it states that there is an effect rapid changes in improving the marketing mix of livestock in Jordan.

Sub-fifth hypothesis: There is no statistically significant effect at the significance level $(\alpha \geq 0.05)$ cooperation on improving the marketing mix of livestock in Jordan.

Table 15. Simple linear regression analysis of the to cooperation variable

\begin{tabular}{lllll}
\hline Model Summary & & & \\
Model & R & R Square & Adjusted R Square & Std. An error of the \\
Estimate
\end{tabular}

a. Predictors: (Constant), cooperation.

It is clear from the previous table that the cooperation variable explains the amount (18.9\%) of improving the marketing mix of livestock in Jordan.

Table 16. Analysis of variance of the cooperation variable

\begin{tabular}{|c|c|c|c|c|c|c|}
\hline \multicolumn{7}{|c|}{ ANOVAs } \\
\hline & & Sum of Squares & df & Mean Square & $\mathrm{F}$ & Sig. \\
\hline \multirow[t]{3}{*}{1} & Regression & 0.164 & 1 & 0.164 & 0.246 & $.878 \mathrm{~b}$ \\
\hline & Residual & 215.126 & 498 & .431 & & \\
\hline & Total & 215.290 & 499 & & & \\
\hline
\end{tabular}

a. Dependent Variable: improve marketing mix.

b. Predictors: (Constant), cooperation.

It is clear from the previous table that there is no statistically significant effect of the cooperation variable in improving the marketing mix of livestock in Jordan, as the calculated value (sig) reached $(0.878)$ which is bigger than the level of significance $(\alpha \geq 0.05)$.

Sub-sixth hypothesis: There is no statistically significant effect at the significance level $(\alpha \geq 0.05)$ government Efficiency on improving the marketing mix of livestock in Jordan. 
Table 17. Simple linear regression analysis of the government Efficiency variable

\begin{tabular}{lllll}
\hline \multicolumn{3}{l}{ Model Summary } & & Std. An error of the \\
Model & $\mathrm{R}$ & R Square & Adjusted R Square & Estimate \\
1 & $.887 \mathrm{a}$ & .871 & .871 & .24708 \\
\hline
\end{tabular}

a. Predictors: (Constant), government efficiency

It is clear from the previous table that the government efficiency variable explains the amount $(87.1 \%)$ of improving the marketing mix of livestock in Jordan.

Table 18. Analysis of variance of the government efficiency variable

\begin{tabular}{|c|c|c|c|c|c|c|}
\hline \multicolumn{7}{|c|}{ ANOVAs } \\
\hline Model & & Sum of Squares & df & Mean Square & $\mathrm{F}$ & Sig. \\
\hline \multirow[t]{3}{*}{1} & Regression & 66.240 & 1 & 66.240 & 221.319 & $.000 \mathrm{~b}$ \\
\hline & Residual & 149.050 & 498 & .299 & & \\
\hline & Total & 215.290 & 499 & & & \\
\hline
\end{tabular}

a. Dependent Variable: improve marketing mix.

b. Predictors: (Constant), government efficiency.

It is clear from the previous table that there is a statistically significant effect of the government efficiency variable in improving the marketing mix of livestock in Jordan, as the calculated value (sig) reached $(0.000)$ which is less than the level of significance ( $\alpha \geq 0.05$ ), thus rejecting the nihilistic hypothesis and accepting the alternative which it states that there is an effective government efficiency in improving the marketing mix of livestock in Jordan.

Sub-seventh hypothesis: There is no statistically significant effect at the significance level $(\alpha \geq 0.05)$ cost on improving the marketing mix of livestock in Jordan.

Table 19. Simple linear regression analysis of the to cost variable

\begin{tabular}{|c|c|c|c|c|}
\hline \multicolumn{5}{|c|}{ Model Summary } \\
\hline Model & $\mathrm{R}$ & R Square & Adjusted R Square & $\begin{array}{l}\text { Std. An error of the } \\
\text { Estimate }\end{array}$ \\
\hline 1 & $.931 \mathrm{a}$ & .921 & .921 & .54448 \\
\hline
\end{tabular}

a. Predictors: (Constant), cost.

It is clear from the previous table that the cost variable explains the amount $(92.1 \% \%)$ of improving the marketing mix of livestock in Jordan.

Table 20. Analysis of variance of the cost variable

\begin{tabular}{|c|c|c|c|c|c|c|}
\hline \multicolumn{7}{|c|}{ ANOVAs } \\
\hline Model & & Sum of Squares & df & Mean Square & $\mathrm{F}$ & Sig. \\
\hline \multirow[t]{3}{*}{1} & Regression & 67.656 & 1 & 67.656 & 228.217 & $.000 \mathrm{~b}$ \\
\hline & Residual & 147.634 & 498 & .296 & & \\
\hline & Total & 215.290 & 499 & & & \\
\hline
\end{tabular}

a. Dependent Variable: improve marketing mix.

b. Predictors: (Constant), cost.

It is clear from the previous table that there is a statistically significant effect of the cost variable in improving the marketing mix of livestock in Jordan, as the calculated value (sig) reached (0.000) which is less than the level of significance $(\alpha \geq 0.05)$, thus rejecting the nihilistic hypothesis and accepting the alternative which it states that 
there is an effective cost in improving the marketing mix of livestock in Jordan.

Sub-eighth hypothesis: There is no statistically significant effect at the significance level $(\alpha \geq 0.05)$ Technology on improving the marketing mix of livestock in Jordan.

Table 21. Simple linear regression analysis of the to Technology variable

\begin{tabular}{lllll}
\hline Model Summary & & & \\
& & & & Std. An error of the \\
Model & $\mathrm{R}$ & R Square & Adjusted R Square & Estimate \\
\hline 1 & .831 & .821 & .821 & .55850 \\
\hline
\end{tabular}

a. Predictors: (Constant), technology.

It is clear from the previous table that the technology variable explains the amount $(82.1 \% \%)$ of improving the marketing mix of livestock in Jordan.

Table 22. Analysis of variance of the technology variable

\begin{tabular}{lllllll}
\hline $\begin{array}{l}\text { ANOVAs } \\
\text { Model }\end{array}$ & & Sum of Squares & df & Mean Square & F & Sig. \\
\hline 1 & Regression & 59.951 & 1 & 59.951 & 192.196 & $.000 \mathrm{~b}$ \\
& Residual & 155.339 & 498 & .312 & & \\
& Total & 215.290 & 499 & & & \\
\hline
\end{tabular}

a. Dependent Variable: improve marketing mix.

b. Predictors: (Constant), technology.

It is clear from the previous table that there is a statistically significant effect of the technology variable in improving the marketing mix of livestock in Jordan, as the calculated value (sig) reached (0.000) which is less than the level of significance ( $\alpha \geq 0.05$ ), thus rejecting the nihilistic hypothesis and accepting the alternative which it states that there is an effective technology in improving the marketing mix of livestock in Jordan.

\section{References}

Al Mullah, A. (2011). Determinants Factors of Tourists Satisfaction in Muslim Countries: A Structural Equation Model (SEM).

Alan, H. H., Skip, W., \& Remake, V. (2019). Logistics Management and Strategy Competing through the Supply Chain (5th ed.).

Alex, G., Karla, S., \& Cara, W. (2017). Digital Channels' for Building Collaborative Consumption Communities. Journal of Research in Interactive Marketing, 11(2).

Ali. H. J. (2011). Quantitative trends in management (2nd ed.).

Amen, M. Y., \& Peters, K. (2006). Owasso Sheep Production and the Development of breeding Program Option in Syria. Humboldt University.

Chen, C., \& Tsai, D. C. (207). How Destination Image and evaluative Factors Affect Behavioral Intentions? Tourism Management, 28(4), 1115-1122.

Colin, B., \& Paul, B. (2018). The Business Plan Workbook: A step-by-Step-Guide to Creating and Developing a Successful Business.

Geoff, R., \& Catherine, M. (2015). Inventory Management: Advanced Methods for Managing Inventory within Business System.

Hassan, A. A. (2019). Concept of Internet Marketing as a modern Organization Developed Paradigm. International Journal of Innovative Technology and Exploring Engineering.

Hellenes, S. (2010). Marketing Management: A Relationship Approach. London: Financial Times Prentice Hall.

Jay, B., \& William, H. (2019). Strategic Management and Competitive Advantage (6th ed.).

Jeffry, P. (219). Project Management: Achieving Competitive Advantage (5th ed.). 
Jo, O. (2018). How to Manage: The Definitive Guide to Effective Management (5th ed.).

John, W., \& Kenneth, W. (2019). International Business the Challenges of Globalization (9th ed.).

Karle, J. A. (2019). Applied Strategic Marketing, A Step by Step Approach (1st ed.).

Kombis, H. H., Mona, S. (2010). The Impact of Corporate Social Responsibility on Customer satisfaction and Corporate Reputation in automotive Industry. Journal of Islamic marketing, 5(1).

Kovaltchuk, A. P., Miloradov, E. A. (2017). Increasing the Competitiveness of the Russian Hotel Enterprise Under Modern Conditions. Journal of environmental management and tourism, 2(18), 407-416.

Lin, H. F. (2008). Determinants of Successful Virtual Communities: Contribution from system characteristics and social factors. Information and Management, 45(8), 522-527.

Marikina, E. I. (2017). Marketing in Industries and Fields of activity. Moscow: DashkoviKo.

Marshal, S., \& Gopher, F. K. (2018). Digital Analytics for Marketing.

Martin, C., \& Alan, B. (2015). Business Operation Models: Becoming a Disruptive Competitor.

Mohlaman, M. (2015). Collaborative Consumption: determinants of satisfaction and likelihood of using a sharing economy option again. Journal of Consumer Behavior, 12(4), 253-266.

Muss, F. (2010). Innovation in Marketing Channels' symphony. Engineering Issues in Management, 1, 23-41.

Oshaughan, E. (2016). Business Organization, RLE Organization.

Pedersen, E. R. G., \& Netter, S. (2015). Collaborative Consumption: business model opportunities and barriers for fashion libraries. Journal of Fashion Marketing and Management, 19(3), 258-273.

Raid, J. G., \& Jason, G. (2017). Global Business, Competitiveness and Sustainability.

Report. (2017). Arab livestock wealth.

Roscoe, I. V. (2014). Information Systems and Technologies in marketing. Moscow: Ru-science.

Sera, M. (2012). We Create Us Connect, we respect, and therefore we are intellectual, social, and cultural value in online communities. Journal of Interactive Marketing, 26(4), 209-222.

Serves, P., Rasmussen, E., \& Madsen, T. K. (2006). Small Manufacturing Firms' Involvement E-Business Activities. Advance in international Marketing, 17, 297-318.

Shard, A. D., \& Turban, K. (2018). Business Intelligence: A Managerial Approach.

Site Trip in The Arab World. (2017). Obstacles to the development of animal wealth in the Arab world, policies and services.

Steve, C/, Tony, K., \& Arnold, A. (2016). Introduction to Management (8th ed.).

Stone, M. D., \& Woodcock, N. D. (2014). Interactive, direct and digital marketing: a future that depends on better use of business intelligence. Journal of research in interactive marketing, 8(1), 4-17.

Tap, A., \& Hughes, T. (2004). New Technology and the changing role of marketing. Marketing Intelligence Planning, 22, 284-296.

Tim, H., \& Adam, G. (2018). Marketing: How to Achieve Competitive Advantage through Blended Sales and marketing.

Tucker, A., \& Tichner, U. (2006). New Business for Old Europe: Product-Services Development, Competitiveness, and Sustainability.

Warren, M. (2004). Farmers online: drivers and impediments in the adoption of internet UK agricultural business, Journal of Small Business and Enterprise Development, 11, 371-381.

Williams, A. (2006). Product -Service System in the automotive industry: the case of micro-factory retailing. Journal of cleaner production, 14, 172-184.

Williams. (2007). A Product-Service Systems in the automobile industry: contribution to system innovation. Journal of Cleaner Production, 15(12), 1093-1103.

Yuldasheva, O. U. (2004). Cognitive Marketing: from the promotion of products to the promotion of consumption technology. Market Communications, 5(23), 36-40. 


\section{Copyrights}

Copyright for this article is retained by the author(s), with first publication rights granted to the journal.

This is an open-access article distributed under the terms and conditions of the Creative Commons Attribution license (http://creativecommons.org/licenses/by/4.0/). 